\title{
Assessment of surface temperatures of buffalo bulls (Bubalus bubalis) raised under tropical conditions using infrared thermography
}

\author{
[Avaliação de temperaturas superficiais de touros bubalinos (Bubalus bubalis) criados em \\ ambiente tropical com uso da termografia infravermelha] \\ D.V. Barros ${ }^{1}$, L.K.X. Silva ${ }^{1}$, P.R. Kahwage ${ }^{1}$, J.B. Lourenço Júnior ${ }^{1}$, J.S. Sousa ${ }^{1}$, \\ A.G.M. Silva ${ }^{1}$, I.M. Franco ${ }^{1}$, L.G. Martorano ${ }^{2}$, A.R. Garcia ${ }^{3}$. \\ ${ }^{1}$ Universidade Federal do Pará -Belém, PA \\ ${ }^{2}$ Embrapa Amazônia Oriental - Belém, PA \\ ${ }^{3}$ Embrapa Pecuária Sudeste - São Carlos, SP
}

\begin{abstract}
This paper aimed to evaluate the surface temperatures of buffalo bulls using infrared thermography, considering four distinct anatomical parts over time, and to correlate surface temperatures and thermal comfort indexes. The humid tropical climate (Köppen's Afi) was predominant in the research station where the experiment was performed and the trial lasted from April to August. Ten bulls $(n=10)$ were evaluated every 25 days (morning: 6:00-9:00; afternoon: 12:00-15:00) and the parameters assessed were respiratory rate (RR), rectal temperature (RT), and the thermograms of surface temperature for orbital area (ORB), right flank (RF), left flank (LF) and scrotum (SCR). Climatological data was continuously monitored and the Temperature and Humidity Index (THI) and the Index of Comfort of Benezra (ICB) were calculated. The average values of THI were $\geq 78$, and significant differences between shifts were observed $(\mathrm{P}<0.05)$. The ICB ranged from 1.96 to 2.25 and significant differences were observed for shifts and throughout the months $(\mathrm{P}<0.05)$. The averages of surface temperatures were $\mathrm{RT}=38.2 \pm 0.5^{\circ} \mathrm{C}$, $\mathrm{ORB}=36.1 \pm 0.8^{\circ} \mathrm{C}, \mathrm{LF}=33.5 \pm 2.5^{\circ} \mathrm{C}, \mathrm{RF}=35.4 \pm 1.7^{\circ} \mathrm{C}$ and $\mathrm{SCR}=33.3 \pm 1.1^{\circ} \mathrm{C}$, which exhibited significant differences for shifts and throughout the months $(\mathrm{P}<0.05)$. Positive correlations were obtained between THI and ORB (0.72), RF (0.77), LF (0.75) and SCR (0.41) $(\mathrm{P}<0.0001)$. The maximum temperature of ORB showed the highest correlation with RT $(0.58, \mathrm{P}<0.0001)$. Therefore, the surface temperatures are subject to climatic variations and increase throughout the day, due to the variation in thermal comfort indexes, and the maximum ORB temperature was the parameter most related to rectal temperature. Lastly, the results indicate that IRT may be a useful non-invasive and accurate tool to detect the variations in ORB, LF, RF and SCR temperature in buffalo bulls.
\end{abstract}

Keywords: animal welfare, water buffalo, infrared imaging, core temperature, body surface temperature

\section{RESUMO}

O presente trabalho visou avaliar as temperaturas superficiais de diferentes regiões anatômicas de búfalos ao longo do tempo, por meio da termografia infravermelha, e correlacioná-las a indices bioclimatológicos de conforto térmico. O ensaio foi realizado em região de clima tropical úmido (Afi de Köppen), de abril a agosto. Dez touros $(n=10)$ foram avaliados a cada 25 dias (manhã: seis-nove horas; tarde: 12-15h), quanto à frequência respiratória (FR), temperatura retal (TR) e imagens termográficas da órbita ocular (ORB), flanco direito (FLd), flanco esquerdo (FLe) e escroto (ESC). Os dados climatológicos foram ininterruptamente monitorados, e calculados o indice de temperatura e umidade (ITU) e o indice de conforto de Benezra (ICB). O ITU foi $\geq 78$, com diferença entre turnos $(P<0,05)$. Já o ICB variou de 1,96 a 2,25 e apresentou diferenças ao longo dos meses e entre turnos $(P<0,05)$. As temperaturas observadas foram de $T R=38,2 \pm 0,5^{\circ} \mathrm{C}, \quad$ ORB $=36,1 \pm 0,8^{\circ} \mathrm{C}, \quad F L d=33,5 \pm 2,5^{\circ} \mathrm{C}$,

Recebido em 30 de março de 2015

Aceito em 9 de dezembro de 2015

* Autor para correspondência (corresponding author)

E-mail: alexandre.garcia@embrapa.br 
$F L e=35,4 \pm 1,7^{\circ} \mathrm{C}$ e $E S C=33,3 \pm 1,1^{\circ} \mathrm{C}$, as quais variaram significativamente ao longo dos meses e entre turnos $(P<0,05)$. O ITU apresentou correlações positivas com ORB $(0,72)$, FLd $(0,77)$, FLe $(0,75)$ e ESC $(0,41)(P<0,0001)$. A temperatura máxima de ORB apresentou a maior correlação com a TR $(0,58$; $P<0,0001)$. Portanto, as temperaturas superficiais dos animais sofrem interferências das variações climáticas e se elevam ao longo do dia, devido à variação nos índices de conforto térmico; a temperatura máxima de ORB foi o parâmetro mais condicionado à temperatura retal. Também, as oscilações de temperatura de superficie de ORB, FLd, FLe e ESC podem ser aferidas em bubalinos com o uso da termografia infravermelha, de modo preciso e não invasivo.

Palavras-chave: bem-estar animal, búfalo doméstico, imagem infravermelha, temperatura interna, temperatura corpórea superficial

\section{INTRODUCTION}

Water buffalo breeding is an activity of great economical potential and the global buffalo herd has grown in an annual rate of over $2 \%$ in the last two decades, mainly in developing countries (Sethi, 2013). The buffalo is a homeothermic animal, but when submitted to elevated temperatures and relative humidity may undergo heat stress (Moraes Júnior et al., 2010). However, around $85 \%$ of domestic buffaloes are raised in the intertropical zone, which predisposes these animals to a situation of permanent thermal challenge (Garcia, 2013). Since heat stress is a challenge for reaching superior animal husbandry indexes, different technologies in environmental and animal monitoring have been employed in the called "precision farming". Their use allows for the evaluation of environmental effects on animal production and can aid in decision making in herd management (Hoffmann et al., 2013).

The infrared thermography (IRT) is a noninvasive evaluation technique that has been used in Veterinary Medicine as a tool to aid in the precocious diagnosis of affections (Luzi et al., 2013). There are previous reports of the use of IRT in the evaluation of infectious diseases in the respiratory tract (Schaefer et al., 2012), hoof disorders (Stokes et al., 2012) and in monitoring the methane emission in ruminants (Montanholi et al., 2008). However, work with the use of IRT for the buffalo species has not yet been described in literature, and the thermographic standards for buffalo are still unknown. This information is relevant because it can increase knowledge on the role of body surface of buffalo in the thermolysis process, as well as generate new thermographic information that may aid in the husbandry of animals raised in a tropical climate, aiming to avoid heat stress. Thus, the aim of the present work was to evaluate in time the surface temperatures of different anatomical areas (orbital area, right and left flank and scrotum) through infrared thermography and correlate this information with the variations in bioclimatological indexes of thermal comfort for buffalo raised in a tropical climate region.

\section{MATERIALS AND METHOD}

The experiment took place at the Center of Animal Reproduction Biotechnology (CEBRAN), which belongs to the Federal University of Pará, located in the city of Castanhal (1 $1^{\circ} 18^{\prime} 18^{\prime \prime} \mathrm{S}$ and $\left.47^{\circ} 56^{\prime} 36^{\prime \prime} \mathrm{W}\right)$, Pará, Brazil. The region has a humid tropical climate (Koppen's Afi), megathermal, with annual rainfall between 2300 and $2800 \mathrm{~mm}$ and monthly rainfall above or equal to $60 \mathrm{~mm}$ (Alvares et al., 2013). The experimental period included the months of April through August 2013, a total of 22 weeks. The experiment followed the bioethics precepts in animal experimentation and the protocols adopted were previously approved by the Internal Technical Committee at Embrapa Amazônia Oriental, Brazil.

Ten Murrah buffalo bulls (Bubalus bubalis) were

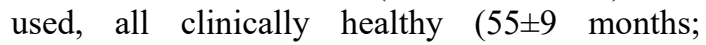
$701.4 \pm 82.8 \mathrm{~kg}$ ). The animals were kept in collective stalls with concrete floors and corded sides $\left(18 \mathrm{~m}^{2} /\right.$ animal). Surrounding the stalls there was forest essence planted in line (Ficus benjamina), with a 0.8 meter spacing. The trees were approximately 14 meters high and had dense foliage, projecting shade in part of the stall areas, offering $7 \mathrm{~m}^{2}$ of shade per animal during the day. There was an adaptation to intensive and feed husbandry during 30 days before the beginning of the experiment. The animals had ad libitum access to the automatic drinking fountain and trough, and food was offered daily in two periods (08h00 and 16h00). The feed was 
composed of ground fodder (Pennisetum purpureum) and a concentrate based on bean residue $(30 \%)$, wheat bran $(68.5 \%)$ and a mineral mixture (1.5\%). The bulk was offered ad libitum and the concentrate was calculated for a daily offer of $1 \%$ of the live weight of animals.

The climatic characterization in the experimental period was done based on data for solar radiation, rainfall, temperature and relative humidity, obtained without interruption in the meteorological station for automatic surfaces in the Instituto Nacional de Meteorologia, Brazil (INMET). The station was located approximately 750 meters from the location where animals were maintained $\left(1^{\circ} 18^{\prime} 03^{\prime \prime} \mathrm{S}\right.$ and 47 $\left.56^{\prime} 51^{\prime \prime} \mathrm{W}\right)$ and registered the values observed every minute. To characterize the microclimate inside the stalls, temperature and relative humidity were monitored without interruption using three dataloggers $\left(\mathrm{HOBO}^{\circledR} \mathrm{U} 12-012\right.$, Onset Computer Corporation, Bourne, MA, USA), installed suspended 2.0 meters from the ground, 9 meters distance from each other, and maintained in meteorological shelters protected from direct sunlight and water (Malama et al., 2013). The data registered by the dataloggers every 15 minutes was weekly transferred to an analysis software (HOBOware ${ }^{\circledR}$ Lite 3.1.0, Onset Computer Corporation, Bourne, MA, EUA) and the average values registered by the three dataloggers were used in posterior calculations.

The temperature and humidity index inside the stalls (THI) was calculated for morning (6h00 to $9 \mathrm{~h} 00$ ) and afternoon (12h00 to 15h00) shifts, according to the following formula: $\mathrm{THI}=(0.8$ AT $)+(\mathrm{RH} / 100) \times[(\mathrm{AT}-14.4)+46.4]$, where AT is the air temperature in a dry bulb thermometer $\left({ }^{\circ} \mathrm{C}\right)$ and $\mathrm{RH}$ is the relative humidity (\%) according to Thom (1959). To determine the index of comfort of Benezra (ICB) the following formula was used: $\mathrm{ICB}=\mathrm{RT} / 38.33+\mathrm{RR} / 23$, where $\mathrm{RT}$ is the rectal temperature $\left({ }^{\circ} \mathrm{C}\right)$ and $\mathrm{RR}$ is the respiratory rate ( $\mathrm{mov} / \mathrm{min})$, according to Benezra (1954). The respiratory rate (RR) and rectal temperature (RT) were also measured in the morning (6h00 to $9 \mathrm{~h} 00)$ and afternoon (12h00 to $15 \mathrm{~h} 00)$, in order to coincide with THI registrations. The RR was determined through observation of the thoracic-abdominal area and counting the breathing movements during one minute ( $\mathrm{mov} / \mathrm{min})$. To measure RT a veterinary clinical thermometer with a scale up to $44^{\circ} \mathrm{C}$ was used, introduced in the rectum of the animal and maintained for at least one minute or the time required to stabilize the mercury, with the results expressed in degrees centigrade $\left({ }^{\circ} \mathrm{C}\right)$, according to Rosenberger et al. (1993). The physiological parameters were measured with an average interval of 25 days, in two consecutive measuring days, in the morning and afternoon, totalizing 28 measurements per animal.

A single technician performed the infrared thermography, with an IRT camera (FLIR Series A320, FLIR Systems, Inc., Wilsonville, OR, USA). The animals were evaluated in the morning (6h00 to $9 \mathrm{~h} 00)$ and afternoon ( $12 \mathrm{~h} 00$ to 15h00). The total number of images done for thermographic evaluation was 1064, of which there were 266 images for each anatomical area (133 repetitions per shift). The camera was attached to a tripod and had a fixed 25 degree lens, with automatic focus, temperature scale of -20 to $120^{\circ} \mathrm{C}$, thermal sensibility of $50 \mathrm{mK}$ $\left(<0.05^{\circ} \mathrm{C}\right.$ to the ambient temperature of $\left.30^{\circ} \mathrm{C}\right)$, spectral scale from 7.5 to $13 \mu \mathrm{m}$ and optical resolution of $320 \times 240$ pixels. The emission was adjusted to 0.98 as proposed by Hoffmann et al. (2013), and the camera was connected to a 16 inch flat screen monitor for full visualization of the anatomical areas at the moment when the images were acquired. Thermographic images were generated from four different anatomical points: right flank (RF), left flank (LF), orbital area (ORB) and scrotum (SCR), always in this order.

To capture the thermographic images the animals were contained in a cattle crush, and the distances from the camera lens to the analyzed surfaces were $1.50 \mathrm{~m}$ for ORB, RF and LF and $0.70 \mathrm{~m}$ for SCR. In the image evaluation procedure the area used to study ORB was limited by a circular trace on the orbital region, including the ocular globe and $1 \mathrm{~cm}$ of the orbital cavity, according to Schaefer et al. (2012). To analyze images of RF and LF there was a trace in a rectangular polygon autoform, superimposed to the flank area, according to Montanholi et al. (2008). To analyze the SCR images there was a rectangle polygon trace from the dorsal to ventral poles of the testicles, according to Coulter et al. (1997). The IRT images were analyzed using the ThermaCAM Researcher Professional software (version 2.9, FLIR Systems, Inc., Wilsonville, OR, USA). The average temperatures $\left({ }^{\circ} \mathrm{C}\right)$ in 
each image analyzed were calculated to determine the averages in all pixels included in the marked areas, while the minimum and maximum temperatures were taken through automatic identification of cold spots and hot spots, according to Hoffmann et al. (2013).

The statistical treatment for data in physiological parameters and comfort indexes observed contemplated the descriptive statistics (average \pm standard deviation, minimum and maximum) for all variables studied and the normality test. For the variables with abnormal distribution or elevated variation coefficients, transformations were done for the logarithmical scale. We adopted the variance analysis with the GLM procedure by SAS, version 9.3 (SAS, 2011), considering the effects of shift (morning and afternoon) and month (April to August) in the model. For the comparisons of averages between shifts the F-test was used, and for multiple comparisons of the monthly averages the Tukey test was used. The correlation analysis between the parameters was done with the Pearson correlation coefficient. In all statistical analysis the significance level adopted was $\mathrm{P}<0.05$.

\section{RESULTS}

The maximum air temperature presented a general average of $31.5 \pm 0.8^{\circ} \mathrm{C}$, with oscillation below $1^{\circ} \mathrm{C}$ throughout the experiment (Table 1 ). The maximum humidity oscillated between 92.2 and $94.2 \%$, with an average of $93.2 \%$. The rainfall was greater in April, while the month with the least rainfall was June. The solar radiation had the lowest levels in April and May, with elevation throughout the months and greatest value registered in July.

Table 1. Climatological data registered in an automatic meteorological station, in the months of April through August, in Castanhal, Pará, Brazil ( $1^{\circ} 18^{\prime} 18^{\prime \prime} \mathrm{S}$ and $\left.47^{\circ} 56^{\prime} 36^{\prime \prime} \mathrm{W}\right)$

\begin{tabular}{cccccc} 
& April & May & June & July & August \\
\hline MaxAT & 31.1 & 31.5 & 31.8 & 31.3 & 31.6 \\
MaxRH & 93.7 & 94.2 & 92.9 & 93.0 & 92.2 \\
Rainfall & 284.0 & 191.6 & 118.0 & 251.4 & 125.2 \\
Radiation & 620.514 & 651.152 & 710.356 & 716.247 & 714.578 \\
\hline
\end{tabular}

MaxAT average monthly maximum air temperature $\left({ }^{\circ} \mathrm{C}\right), \operatorname{Max} R H$ average monthly maximum reltive humidity $(\%)$, Rainfall accumulated monthly rainfall $(\mathrm{mm})$, Radiation average monthly solar radiation $\left(\mathrm{kJ} / \mathrm{m}^{2}\right)$.

The THI observed in time presented an average always above 78, with no differences among months $(\mathrm{P}>0.05)$. The THI was always more elevated in the afternoon shift $(\mathrm{P}<0.05)$, with greater increments (4 to 6 points) in the months of June, July and August (Table 2). The ICB values were also greater in the afternoon. In time, the ICB was maintained initially stable during the months of April and May, but presented a gradual increase starting in June and reached the highest values in the months of July and August $(\mathrm{P}<0.05)$.

Table 2. Average values and standard deviation of THI and ICB for buffalo bulls (Bubalus bubalis) during the morning ( $6 \mathrm{~h} 00$ to $9 \mathrm{~h} 00$ ) and afternoon (12h00 to 15h00) shifts, in the months of April through August, in Castanhal, Pará, Brazil

\begin{tabular}{rccccccc}
\hline & Shift & April & May & June & July & August & $\begin{array}{c}\text { General } \\
\text { Average }\end{array}$ \\
& & & & & & & $77.90^{\mathrm{y}}$ \\
\multirow{3}{*}{ THI } & M & $79.2 \pm 2.8^{\mathrm{x}}$ & $78.1 \pm 2.2^{\mathrm{y}}$ & $77.4 \pm 2.7^{\mathrm{y}}$ & $75.9 \pm 2.9^{\mathrm{y}}$ & $77.9 \pm 2.0^{\mathrm{y}}$ & $77.7 \pm 2.6^{\mathrm{y}}$ \\
& A & $82.1 \pm 2.9^{\mathrm{x}}$ & $80.5 \pm 1.5^{\mathrm{x}}$ & $83.4 \pm 0.8^{\mathrm{x}}$ & $80.4 \pm 2.3^{\mathrm{x}}$ & $82.1 \pm 1.3^{\mathrm{x}}$ & $81.8 \pm 2.1^{\mathrm{x}}$ \\
& Average & $80.6 \pm 3.1$ & $79.3 \pm 2.2$ & $80.4 \pm 3.6$ & $78.2 \pm 3.4$ & $80.0 \pm 2.7$ & $79.7 \pm 3.1$ \\
& & & & & & & \\
ICB & M & $1.93 \pm 0.09^{\mathrm{x}}$ & $1.92 \pm 0.07^{\mathrm{y}}$ & $2.00 \pm 0.07^{\mathrm{y}}$ & $2.12 \pm 0.04^{\mathrm{y}}$ & $2.07 \pm 0.07^{\mathrm{y}}$ & $2.00 \pm 0.10^{\mathrm{y}}$ \\
& A & $1.99 \pm 0.07^{\mathrm{x}}$ & $2.01 \pm 0.05^{\mathrm{x}}$ & $2.08 \pm 0.06^{\mathrm{x}}$ & $2.38 \pm 0.10^{\mathrm{x}}$ & $2.30 \pm 0.14^{\mathrm{x}}$ & $2.13 \pm 0.16^{\mathrm{x}}$ \\
& Average & $1.96 \pm 0.08^{\mathrm{c}}$ & $1.96 \pm 0.08^{\mathrm{c}}$ & $2.04 \pm 0.08^{\mathrm{b}}$ & $2.25 \pm 0.15^{\mathrm{a}}$ & $2.19 \pm 0.15^{\mathrm{a}}$ & $2.06 \pm 0.15$ \\
\hline
\end{tabular}

THI temperature and humidity index in the stall microclimate, $I C B$ index of comfort of Benezra, $M$ morning, $A$ afternoon, Average averages.

a, b, c Averages with different superscripts in the lines differ significantly $(\mathrm{P}<0.05)$.

${ }^{\mathrm{x}, \mathrm{y}}$ Averages with different superscripts in the columns differ significantly $(\mathrm{P}<0.05)$. 
The RT presented a significant increase in the afternoon $(\mathrm{P}<0.05)$, regardless of the month analyzed (Table 3). The general RT averages also presented a significant difference between shifts $(\mathrm{P}<0.05)$. The maximum RT values were observed in the months of April and June, with a significant reduction in the months of July and August $(\mathrm{P}<0.05)$. The ORB, RF, LF and SCR surface temperatures presented increase in the afternoon. The greatest amplitudes observed between shifts in the surface temperatures occurred in the months of June and July, and the lowest amplitudes were observed in April. The surface temperature values for ORB presented oscillations between 35.8 and $36.6^{\circ} \mathrm{C}$, with a general average, regardless of shift, of $36.1 \pm 0.8$. For the RF and LF surface temperatures the oscillations were from 32.3 to $34.5^{\circ} \mathrm{C}$ and 32.9 to $34.8^{\circ} \mathrm{C}$, respectively. The SCR surface temperature was from 33.0 to $33.7^{\circ} \mathrm{C}$. The variations in surface temperature throughout the months presented similar behaviors, with lower values observed in July $(\mathrm{P}<0.05)$ for $\mathrm{ORB}, \mathrm{RF}$ and LF. There was a reduction in the SCR values in the months of May and July $(\mathrm{P}<0.05)$.

Among the correlations observed between THI and ICB with the surface temperatures, the most significant and elevated were between THI and avRF (0.77; P $<0.0001)$, THI and avLF $(0.75$; $\mathrm{P}<0.0001)$, THI and ORB $(0.72 ; \mathrm{P}<0.0001)$, and THI and avSCR $(0.41 ; \mathrm{P}<0.0001)$. Positive correlations, although smaller, were also observed between THI and RT $(0.40 ; \mathrm{P}<0.0001)$, THI and ICB (0.34; $\mathrm{P}<0.0001)$, ICB and avSCR $(0.25 ; \mathrm{P}<0.0001)$ and ICB and RT (0.19; $\mathrm{P}<0.0001)$. The correlation coefficients between $\mathrm{RT}$ and the surface temperatures presented a variation from 0.41 to $0.58 \quad(\mathrm{P}<0.0001)$, the greatest being between RT and maxORB (Table 4). Correlations with lower intensity were observed between RT and avSCR (0.48), RT and avRF (0.49) and RT and avLF (0.49). Greater correlations were found between the surface temperatures, being 0.77 for minSCR and avRF and for minSCR and avLF. For maxSCR and avRF the correlation observed was 0.60 and for maxSCR and avLF it was $0.61(\mathrm{P}<0.0001)$.

Table 3. Average values and standard deviation of the rectal temperature and surface temperatures for orbital area, right flank, left flank and scrotum in buffalo bulls (Bubalus bubalis), registered in the morning (6h00 to 9h00) and afternoon (12h00 to 15h00) shifts, from April to August, in Castanhal, Pará, Brazil

\begin{tabular}{|c|c|c|c|c|c|c|c|}
\hline & Shift & April & May & June & July & August & $\begin{array}{l}\text { General } \\
\text { Average }\end{array}$ \\
\hline \multirow{3}{*}{ RT } & $\mathrm{M}$ & $38.0 \pm 0.7^{y}$ & $38.0 \pm 0.3^{\mathrm{y}}$ & $38.2 \pm 0.3^{y}$ & $37.8 \pm 0.4^{\mathrm{y}}$ & $37.6 \pm 0.7^{y}$ & $38.0 \pm 0.5^{y}$ \\
\hline & A & $38.9 \pm 0.4^{\mathrm{x}}$ & $38.4 \pm 0.3^{x}$ & $38.6 \pm 0.3^{x}$ & $38.5 \pm 0.3^{x}$ & $38.0 \pm 0.6^{\mathrm{x}}$ & $38.4 \pm 0.4^{\mathrm{x}}$ \\
\hline & Average & $38.4 \pm 0.7^{\mathrm{a}}$ & $38.2 \pm 0.4^{\mathrm{ab}}$ & $38.4 \pm 0.4^{\mathrm{a}}$ & $38.1 \pm 0.5^{\mathrm{bc}}$ & $37.8 \pm 0.7^{\mathrm{c}}$ & $38.2 \pm 0.5$ \\
\hline \multirow{3}{*}{ ORB } & M & $36.3 \pm 0.4^{\mathrm{y}}$ & $35.5 \pm 0.6^{\mathrm{y}}$ & $35.6 \pm 0.6^{\mathrm{y}}$ & $35.1 \pm 0.8^{\mathrm{y}}$ & $35.9 \pm 0.7^{\mathrm{y}}$ & $35.6 \pm 0.7^{y}$ \\
\hline & A & $36.8 \pm 0.5^{\mathrm{x}}$ & $36.4 \pm 0.5^{\mathrm{x}}$ & $36.9 \pm 0.7^{\mathrm{x}}$ & $36.6 \pm 0.5^{\mathrm{x}}$ & $36.8 \pm 0.7^{\mathrm{x}}$ & $36.7 \pm 0.6^{\mathrm{x}}$ \\
\hline & Average & $36.6 \pm 0.5^{\mathrm{a}}$ & $35.9 \pm 0.7^{\mathrm{bc}}$ & $36.3 \pm 0.9^{\mathrm{ab}}$ & $35.8 \pm 1.0^{\mathrm{c}}$ & $36.3 \pm 0.8^{\mathrm{ab}}$ & $36.1 \pm 0.8$ \\
\hline \multirow{3}{*}{ RF } & M & $34.3 \pm 1.9^{\mathrm{x}}$ & $31.9 \pm 1.8^{\mathrm{y}}$ & $31.7 \pm 1.9^{\mathrm{y}}$ & $30.0 \pm 1.4^{y}$ & $32.8 \pm 2.0^{y}$ & $31.9 \pm 2.1^{\mathrm{y}}$ \\
\hline & A & $34.7 \pm 2.3^{x}$ & $34.5 \pm 1.4^{\mathrm{x}}$ & $36.0 \pm 1.3^{\mathrm{x}}$ & $34.6 \pm 1.2^{x}$ & $35.8 \pm 1.7^{\mathrm{x}}$ & $35.2 \pm 1.6^{\mathrm{x}}$ \\
\hline & Average & $34.5 \pm 2.1^{\mathrm{a}}$ & $33.2 \pm 2.1^{\mathrm{bc}}$ & $33.8 \pm 2.7^{\mathrm{ab}}$ & $32.3 \pm 2.6^{\mathrm{c}}$ & $34.5 \pm 2.4^{\mathrm{ab}}$ & $33.5 \pm 2.5$ \\
\hline \multirow{3}{*}{$\mathrm{LF}$} & M & $34.7 \pm 1.7^{\mathrm{x}}$ & $32.0 \pm 1.6^{\mathrm{y}}$ & $32.4 \pm 1.9^{\mathrm{y}}$ & $31.0 \pm 1.1^{\mathrm{y}}$ & $33.1 \pm 2.0^{y}$ & $32.4 \pm 2.0^{\mathrm{y}}$ \\
\hline & A & $34.9 \pm 2.1^{\mathrm{x}}$ & $34.6 \pm 1.7^{\mathrm{x}}$ & $36.2 \pm 1.3^{\mathrm{x}}$ & $34.9 \pm 1.3^{\mathrm{x}}$ & $36.2 \pm 1.7^{x}$ & $35.4 \pm 1.7^{x}$ \\
\hline & Average & $34.8 \pm 1.9^{\mathrm{a}}$ & $33.3 \pm 2.1^{\mathrm{bc}}$ & $34.3 \pm 2.5^{\mathrm{ab}}$ & $32.9 \pm 2.3^{\mathrm{c}}$ & $34.7 \pm 2.4^{\mathrm{a}}$ & $33.9 \pm 2.4$ \\
\hline \multirow{3}{*}{ SCR } & M & $33.7 \pm 0.8^{\mathrm{x}}$ & $32.7 \pm 0.7^{y}$ & $32.9 \pm 0.9^{y}$ & $32.6 \pm 0.8^{y}$ & $33.2 \pm 1.0^{\mathrm{y}}$ & $32.9 \pm 0.9^{\mathrm{y}}$ \\
\hline & A & $33.7 \pm 1.2^{\mathrm{x}}$ & $33.3 \pm 1.0^{\mathrm{x}}$ & $34.1 \pm 1.1^{\mathrm{x}}$ & $33.6 \pm 1.3^{\mathrm{x}}$ & $34.1 \pm 1.5^{\mathrm{x}}$ & $33.7 \pm 1.2^{x}$ \\
\hline & Average & $33.7 \pm 1.0^{\mathrm{a}}$ & $33.0 \pm 0.9^{\mathrm{b}}$ & $33.5 \pm 1.2^{\mathrm{ab}}$ & $33.1 \pm 1.2^{\mathrm{b}}$ & $33.7 \pm 1.3^{\mathrm{a}}$ & $33.3 \pm 1.1$ \\
\hline
\end{tabular}

$R T$ rectal temperature, $O R B$ surface temperature of the orbital area, $R F$ surface temperature of the right flank, $L F$ surface temperature of the left flank, $S C R$ surface temperature of the scrotum, $M$ morning, $A$ afternoon

$a, b, c$ Averages with different superscripts in the lines differ significantly $(\mathrm{P}<0.05)$

${ }^{\mathrm{x}, \mathrm{y}}$ Averages with different superscripts in the columns differ significantly $(\mathrm{P}<0.05)$ 
Table 4. Pearson correlation coefficients between rectal temperature and surface temperatures measured with infrared thermography in different anatomical areas of buffalo bulls (Bubalus bubalis), during the morning (6h00 to 9h00) and afternoon (12h00 to 15h00) shifts, in the months of April through August, in Castanhal, Pará, Brazil

\begin{tabular}{|c|c|c|c|c|c|c|c|c|c|c|c|c|c|}
\hline & TR & avORB & $\operatorname{minORB}$ & $\operatorname{maxORB}$ & avSCR & minSCR & maxSCR & avRF & $\operatorname{minRF}$ & $\operatorname{maxRF}$ & avLF & $\operatorname{minLF}$ & maxLF \\
\hline TR & 1.00 & & & & & & & & & & & & \\
\hline avORB & $0.51 *$ & 1.00 & & & & & & & & & & & \\
\hline $\operatorname{minORB}$ & $0.41^{*}$ & $0.87^{*}$ & 1.00 & & & & & & & & & & \\
\hline $\operatorname{maxORB}$ & $0.58^{*}$ & $0.81^{*}$ & $0.62 *$ & 1.00 & & & & & & & & & \\
\hline avSCR & $0.48^{*}$ & $0.61 *$ & $0.43 *$ & $0.65^{*}$ & 1.00 & & & & & & & & \\
\hline $\operatorname{minSCR}$ & $0.48^{*}$ & $0.70^{*}$ & $0.60^{*}$ & $0.61 *$ & $0.81 *$ & 1.00 & & & & & & & \\
\hline $\operatorname{maxSCR}$ & $0.41^{*}$ & $0.53^{*}$ & $0.34 *$ & $0.58^{*}$ & $0.88^{*}$ & $0.64 *$ & 1.00 & & & & & & \\
\hline avRF & $0.49^{*}$ & $0.80^{*}$ & $0.74 *$ & $0.68^{*}$ & $0.68^{*}$ & $0.77^{*}$ & $0.60^{*}$ & 1.00 & & & & & \\
\hline $\operatorname{minRF}$ & $0.47^{*}$ & $0.78^{*}$ & $0.74 *$ & $0.65^{*}$ & $0.63^{*}$ & $0.75^{*}$ & $0.53^{*}$ & $0.96^{*}$ & 1.00 & & & & \\
\hline $\operatorname{maxRF}$ & $0.46^{*}$ & $0.78^{*}$ & $0.71^{*}$ & $0.65^{*}$ & $0.63^{*}$ & $0.71^{*}$ & $0.58^{*}$ & $0.95^{*}$ & $0.89^{*}$ & 1.00 & & & \\
\hline avLF & $0.49 *$ & $0.80^{*}$ & $0.73 *$ & $0.67 *$ & $0.69^{*}$ & $0.77 *$ & $0.61 *$ & $0.96^{*}$ & $0.92 *$ & $0.91 *$ & 1.00 & & \\
\hline $\operatorname{minLF}$ & $0.47^{*}$ & $0.79 *$ & $0.76^{*}$ & $0.63^{*}$ & $0.63^{*}$ & $0.76^{*}$ & $0.52^{*}$ & $0.92 *$ & $0.93^{*}$ & $0.86^{*}$ & $0.95^{*}$ & 1.00 & \\
\hline $\operatorname{maxLF}$ & $0.47^{*}$ & $0.76^{*}$ & $0.67 *$ & $0.62 *$ & $0.66^{*}$ & $0.72 *$ & $0.60^{*}$ & $0.90^{*}$ & $0.85^{*}$ & $0.88^{*}$ & $0.94 *$ & $0.86^{*}$ & 1.00 \\
\hline
\end{tabular}

$R T$ rectal temperature, $a v O R B$ average surface temperature of the orbital area, minORB minimal surface temperature of the orbital area, $\max O R B$ maximum surface temperature of the orbital area, $a v S C R$ average surface temperature of the scrotum, minSCR minimal surface temperature of the scrotum, $\max S C R$ maximum surface temperature of the scrotum, avRF average surface temperature of the right flank, minRF minimal surface temperature of the right flank, maxRF maximum surface temperature of the right flank, $a v L F$ average surface temperature of the left flank, $\min L F$ minimal surface temperature of the left flank, $\max L F$ maximum surface temperature of the left flank

$* P<0.0001$

\section{DISCUSSION}

The climatological data for temperature and maximum relative humidity obtained at the meteorological station are compatible with data from the regions in the tropical zone, more precisely Köppen's Afi climatic type (Alvares et al., 2013). In the humid tropical climate regions there are two seasons in the year, which differ basically through the rainfall regime. The more rainy period occurs from December to May, and the least rainy period from June to November. Therefore, the data obtained are in accordance with the historical data found for the region (Alvares et al., 2013), only observing that the month of July was considered unusual regarding the habitual rainfall. Thus, the experimental period (April to August) included a period of seasonal transition, in which buffalo can be more susceptible to environmental stress (Silva et al., 2011). The solar radiation was more intense in the less rainy period, due to less cloudiness.

The THI values registered, always above 75 points, indicate that the animals would be in alert or danger conditions regarding thermal comfort, if taken as frame of reference the interpretation that THI $\leq 74$ is considered ideal for raising buffalo (Somparn et al., 2004). However, the findings in the current study did not indicate a thermal stress situation. Likewise, previous research conducted in the Afi type climate demonstrated that buffalo did not present heat stress or reduction of growth performance when THI was between 73.5 and 82.2 (Moraes Júnior et al., 2010) or when THI varied from 75.0 to 81.0 (Garcia et al., 2011). Regarding ICB, the values found in the present study were similar to those reported by Garcia et al. (2011) for adult buffalo (1.7 to 2.4). According to Benezra (1954), ICB values $\leq 2.0$ represent greater adaptability of the animal to the environment. The increase of ICB through the months may have been caused by the transition between periods with more and less rainfall in the year (Silva et al., 2011), besides more intense solar radiation in the less rainy period.

Considering the differences observed between shifts, the greatest values registered for THI, ICB and RT in the afternoon period were due to an observed elevation in the air temperature and the elevation in intensity of solar radiation, which, according to Silva Júnior et al. (2006), increases throughout the morning, reaching its peak value around noon. The RT values found are in accordance with values described by Haque et al. (2012), of $37.2^{\circ} \mathrm{C}$ and $38.9^{\circ} \mathrm{C}$ for animals maintained in temperatures of $22^{\circ} \mathrm{C}$ and $42^{\circ} \mathrm{C}$, respectively. Despite the RT variation, this was within the physiological limits (Silva et al., 2011). Thus, the smallest values for RT in the months of July and August demonstrated that the animals were efficient in the execution of thermolysis, maintaining their homeothermy. The elevation in surface temperature in the afternoon period is probably due to the increase in the solar radiation intensity throughout the day (Silva Júnior et al., 2006) and the predisposition of buffalo to involuntarily absorb heat load 
(Garcia, 2013). Besides this, the temperature of the external surface of the body is subject to greater influence from environment temperatures and, therefore, is less stable than the internal body temperature (Martello et al., 2010). The general average for ORB found in the present work $\left(36.1 \pm 0.8^{\circ} \mathrm{C}\right)$ was slightly below the described by Hoffmann et al. (2013), of $36.9 \pm 0.9^{\circ} \mathrm{C}$, and superior to the described by Schaefer et al. (2012), of $34.7 \pm 0.5^{\circ} \mathrm{C}$, who evaluated adult and calf bovine, respectively. The average values obtained for $\mathrm{RF}\left(33.5 \pm 2.5^{\circ} \mathrm{C}\right)$ and $\operatorname{LF}\left(33.9 \pm 2.4^{\circ} \mathrm{C}\right)$ are similar to those described for adult bovine by Montanholi et al. (2008), of $33.8 \pm 0.3$ and $33.7 \pm 0.2^{\circ} \mathrm{C}$, respectively. The values for SCR temperature are above those described by Coulter et al. (1988), of $30.1^{\circ} \mathrm{C}$, and by Lunstra and Coulter (1997), of $26.7 \pm 0.2^{\circ} \mathrm{C}$, for ovine and bovine, respectively. However, the last authors performed evaluations in the month of April, in a temperate climate region, where the air temperatures are perceptively lower and may interfere directly with the body surface temperature, reducing the absolute values observed.

The correlation coefficients obtained demonstrate that the superficial temperatures in all anatomical areas studied were positively associated with THI and ICB, being the correlations with THI of greater magnitude. This indicates that the increase in the animal's surface temperature is linked to the elevation of air temperature and humidity. This finding is corroborated by the previous results by Martello et al. (2010), who obtained correlations for air temperature and surface temperature of animals between 0.66 and 0.72 . According to Schaefer et al. (2012) and Hoffmann et al. (2013), the maximum surface temperature for the orbital area is the measure that best represents the rectal temperature in bovine. In fact, the results found in the present study indicate that the maximum temperature of the orbital area has the greatest correlation with the rectal temperature, also in buffalo. In addition, the temperature of the orbital area is the thermographic parameter most suitable to evaluate the animal's thermal condition, since it suffers least interference from the environment temperature during the IRT (Gloster et al., 2011). However, one disadvantage for its execution is the need for perfect containment and proximity to the evaluated animal.
Regarding the right and left flank areas, these may also be used when there is difficulty to reach the orbital area, since they are also associated to RT in buffalo. Their evaluation may give information of interest regarding the thermal balance of the animal, since the temperature gradient between the body surface and the air is a physical prerequisite to dissipate heat to the environment (Malama et al., 2013). Besides being used as an indicator of the heat production, the flank temperature has been used in an interesting manner as an indicator of the production of methane in bovine (Montanholi et al., 2008). However, its use must obey certain pre-measurement basic care, because the left flank area presents a pre-prandial temperature elevation (Montanholi et al., 2008).

The surface temperature of the scrotal area suffers effects not only from the internal body temperature, but also the environmental condition, due to the extracavitary position of testicles. The scrotum also has particularities regarding its differentiated thermoregulation mechanism, with thin scrotal skin, relatively devoid of hair, and provided with numerous subcutaneous blood vessels, which promote heat loss (Kastelic, 2014). Thus, the use of scrotal thermography can be very useful to complement the andrologic evaluations (Luzi et al., 2013; Malama et al., 2013). According to Kastelic (2013), the thermography is capable of measuring the surface temperature of the testicles and can be used to evaluate if the bovine bulls are being affected by heat stress, since they present symmetrical thermograms with amplitudes between 4 and $6^{\circ} \mathrm{C}$, which are considered normal regarding the testicular capacity for thermoregulation.

\section{CONCLUSION}

The surface temperatures for orbital area, flank and scrotum suffer interference from the climatic variations, mainly air temperature and humidity, for buffalo bulls raised in a tropical climate. These surface temperatures also present elevation throughout the day, being influenced by the variation in temperature and humidity and the index of comfort of Benezra. The maximum temperature in the orbital area was the parameter most correlated to the rectal temperature and buffalo bulls, and the oscillation in surface temperature of the orbital area, flank and scrotum 
can be measured with the use of infrared thermography, in a precise and non invasive manner.

\section{ACKNOWLEDGMENTS}

This project was financially supported by Embrapa-Brazilian Agricultural Research Corporation (Project PECUS-grant \# 01100600107 and BIOTEC Network-grant \# 01130600105), by the Federal University of Pará (CEBRAN, LADEC) and by CAPESCoordination for Enhancement of Higher Education. The authors also thank to INMET for providing the climatological data and to Waldomiro Barioni Junior for the statistical review.

\section{REFERENCES}

ALVARES, C.A.; STAPE, J.L.; SENTELHAS, P.C. et al. Köppen's climate classification map for Brazil. Meteorol. Z., v.22, p.711-728, 2013.

BASE SAS 9.3 procedures guide. Cary: SAS, 2011.

BENEZRA, M.V. A new index measuring the adaptability of cattle to tropical conditions. $J$. Anim. Sci., v.13, p.1015, 1954.

COUlTER, G.H.; SENGER, P.L.; BAILEY, D.R.C. Relationship of scrotal surface temperature measured by infrared thermography to subcutaneous and deep testicular temperature in the ram. J. Reprod. Fertil., v.84, p.417-423, 1988.

COULTER, G.H.; COOK, R.B.; KASTELIC, J.P. Effects of dietary energy on scrotal surface temperature, seminal quality, and sperm production in young beef bulls. J. Anim. Sci., v.75, p.1048-1052, 1997.

GARCIA, A.R.; MATOS, L.B.; LOURENÇO JÚNIOR, J.B. et al. Variáveis fisiológicas de búfalas leiteiras criadas sob sombreamento em sistemas silvipastoris. Pesqui. Agropecu. Bras., v.46, p.1409-1414, 2011.

GARCIA, A.R. Conforto térmico na reprodução de bubalinos criados em condições tropicais. Rev. Bras. Rep. Anim., v.37 p.121-130, 2013.
GLOSTER, J.; EBERT, K.; GUBBINS, S. et al. Normal variation in thermal radiated temperature in cattle: implications for foot-and-mouth disease detection. BMC Vet. Res., v.7, p.73, 2011.

HAQUE, N.; LUDRI, A.; HOSSAIN, S.A..; ASHUTOSH, M. Comparative studies on temperature threshold for heat shock protein 70 induction in young and adult Murrah buffaloes. J. Anim. Physiol. Anim. Nutr., v.96, p.920-929, 2012.

HOFFMANN, G.; SCHMIDT, M.; AMMON, C. et al. Monitoring the body temperature of cows and calves using video recordings from an infrared thermography camera. Vet. Res. Commun., v.37, p.91-99, 2013.

LUNSTRA, D.D.; COULTER, G.H. Relationship between scrotal infrared temperature patterns and natural-mating fertility in beef bulls. J. Anim. Sci., v.75, p.767-774, 1997.

LUZI, F.; MITCHELL, M.; COSTA, L.N.; REDAELLI, V. Thermography: current status and advances in livestock animals and in veterinary medicine. Brescia, Italy: Fondazione Iniziative Zooprofilattiche e Zootecniche, 2013.

KASTELIC, J.P. Male involvement in fertility and factors affecting semen quality in bulls. Anim. Front., v.3, p.20-25, 2013.

KASTELIC, J.P. Understanding and evaluating bovine testes. Theriogenology, v.81, p.18-23, 2014.

MALAMA, E.; BOLLWEIN, H.; TAITZOGLOU, I.A. et al. Chromatin integrity of ram spermatozoa. Relationships to annual fluctuations of scrotal surface temperature and temperature-humidity index. Theriogenology, v.80, p.533-541, 2013.

MARTELLO, L.S.; SAVASTANO JUNIOR, H.; SILVA, S.L.; BALIEIRO, J.C.C. Alternative body sites for heat stress measurement in milking cows under tropical conditions and their relationship to the thermal discomfort of the animals. Int. J. Biometeorol., v.54, p.647-652, 2010. 
MONTANHOLI, Y.R.; ODONGO, N.E.; SWANSON, K.C. et al. Application of infrared thermography as an indicator of heat and methane production and its use in the study of skin temperature in response to physiological events in dairy cattle (Bos taurus). J. Therm. Biol., v.33, p.468-475, 2008.

MORAES JÚNIOR, R.J.; GARCIA, A.R.; SANTOS, N.F.A. et al. Conforto ambiental de bezerros bubalinos (Bubalus bubalis Linnaeus, 1758) em sistemas silvipastoris na Amazônia Oriental, Acta Amaz., v.40, p.629-640, 2010.

ROSENBERGER, G.; DIRKSEN, G.; GRÜNDER, H.D. et al. Exame clínico dos bovinos. Rio de Janeiro: Guanabara Koogan, 1993, 420p.

SCHAEFER, A.L.; COOK, N.J.; BENCH, C. et $a l$. The non-invasive and automated detection of bovine respiratory disease onset in receiver calves using infrared thermography. Res. Vet. Sci., v.93, p.928-935. 2012.

SETHI, R.K. Breeding strategies for genetic improvement in buffaloes. Buffalo. B., v.32 (Special Issue 1), p.219-226, 2013.
SILVA JÚNIOR, J.A.; COSTA, R.F.; COSTA, A.C.L. et al. Sazonalidade de elementos meteorológicos em ecossistema de manguezal na região equatorial, Pará, Brasil. Rev. Bras. Meteorol., v.21, p.241-247, 2006.

SILVA, J.A.R.; ARAÚJO, A.A.; LOURENÇO JUNIOR, J.B. et al. Conforto térmico de búfalas em sistema silvipastoril na Amazônia Oriental. Pesqui. Agropecu. Bras.,v.46, p.1364-1371, 2011.

SOMPARN, P.; GIBB, M.J.; MARKVICHITR, $\mathrm{K}$. et al. Analysis of climatic risk for cattle and buffalo production in northeast Thailand. Int. J. Biometeorol. v.49, p.59-64, 2004.

STOKES, J.E.; LEACH, K.A.; MAIN, D.C.J.; WHAY, H.R. An investigation into the use of infrared thermography (IRT) as a rapid diagnostic tool for foot lesions in dairy cattle. Vet. J., v.193, p.674-678, 2012.

THOM, E.C. The discomfort index, Weatherwise, v.12, p.57-59, 1959. 